\title{
障害物境界のトポロジーに基づく 未知空間における移動ロボットの経路計画
}

\author{
楊向 東*山本 元 司*毛利彰*
Path Planning for Mobile Robot in Uncertain Workspace Using Obstacle Topology

Xiang Dong Yang*, Motoji Yamamoto* and Akira Mohri*

\begin{abstract}
The problem of path planning is studied for the case of a mobile robot moving in the environment filled with obstacles whose shapes and positions are not known. The robot is assumed to know its own and the target's positions and to have a sensory feedback which provides it with local information on its environment. An aggressive algorithm is proposed using the space topology and convergence and target reachability of the algorithm are explained. Advantages of the algorithm are shown as compared with a number of existing algorithms. Finally, simulation results show effectiveness of the proposed algorithm.
\end{abstract}

Key Words: Mobile Robot, Collision-Free, Sensor-Based Path Planning, Uncertain Workspace

\section{1. まえがき}

衝突回避経路計画はロボット工学の一つの重要な問題であ る.この問題は基礎的なモデルにより二つの種類に分けられ る.一つは，作業環境に関するすべての情報を予め与えるもの である。このような問題沬 Model-Based Approachまたは Piano Mover's Model と呼ばれ[1]，“考えた後で実行する” (Act-After-Thinking) ような計画法である。もう一つは，本 論文で検討する問題であり，作業環境に関する情報が未知（少 なくとも部分的に末知）なものである。このような問題はセン サベーストパスプランニング (Sensor-Based Path Planning) または South Pole Search Problem[2]と呼ばれ，“考えなが ら実行する”（Act-While-Thinking）ような計画法である。セ ンサベーストパスプランニングという問題は，ロボットのセン サからのオンラインの情報により周囲の局所環境を認識し, 目 標に到達できる衝突回避経路を探索するものである。したがっ て, 各ステップの計算量とメモリの要求は少なくなっている が，経路の最適性ということに関して牥何ら情報はなく，また アルゴリズムの収束性が主な問題となる.

センサベーストパスプランニングでは, 二次元の未知環境に おける点ロボットの衝突回避経路計画という問題がまず注目さ れている，本論文ではこの問題について検討する。これまでに

原稿受付 1994 年 5 月 13 日

*九州大学工学部

*Faculty of Engineering, Kyushu University
提案されているいくつかのアルゴリズムはほとんどある直線と 有限な障害物の境界に沿って経路を探索するものである.

Lumelsky らは上述の問題を触覚センサに基づいてモデル化 し，控え目な（conservative）アルゴリズム Bug 1 と積極的な (aggressive) アルゴリズムBug 2 を提案している[3][4]. Bug 1 は目標へ動く経路で頲った障害物の全体の境界を辿って 目標に一番近い点を探し，その点を離脱点 (leave point) とし て目標に単調に接近する衝突点（hit point）と離脱点の系列に より目標に到達するものである。そして経路計画の時に現時点 での目標への方向と目標までの距離さえわかれば現在の位置は 知らなくてもよいという特徵がある $[3]$. Bug 2 は出発点と目 標点をつなぐ直線（M-line）と各障害物境界との交点により目 標に単調に接近する衝突点と離脱点の系列を作り目標に到達す る経路を計画する。 また，Lumelsky らは非触覚センサ情報に 基づく二つのアルゴリズムを提案し，局所センサ情報しか用い ない場合にはいくら良いアルゴリズムでも得られる経路の性質 の改善には上限があることを明らかにしている[5].

さらに, Lumelsky は数学の迷路探索 (Maze-Searching) と センサベーストパスプランニングのアルゴリズムの経路長さの 特徴を比べて次の結論を得ている[6].

(1) 数学の迷路探索アルゴリズムは単にグラフ理論 (Graph Theory）の研究に基づき，迷路のトポロジーを無視し ている.したがって，いくつかのアルゴリズムの経路長さの上 限は Bug 1 より長い.

（2）アルゴリズム Bug 1 と Bug 2 はモデルのトポロジー 
に基づくものである．最もひどい場合の経路の長さを比較する と，いままでのアルゴリズムでは Bug 1 は一番短いものであ る.しかし，多くの場合（最もひどい場合でなく）Bug 2 の経路 の長さは Bug1よりずっと短い.

Lumelsky らの検討に基づき, 作業環境のトポロジーを調べ 一般の場合に対して短い経路を計画するアルゴリズムを提案す ることは衝突回避経路計画の重要な課題になっている. また, 実用的なアルゴリズムという点に関しては，センサとメモリに 対する要求を少なくすることが必要である。，それと同時に，以 下の二つの問題を考えなければならない.

（1）アルゴリズムの収束性：アルゴリズムは有限な時間内 に以下の二つの状態で計算を終了する.（a）出発位置と目標 位置をつなぐ経路が得られた，(b) 目標位置には到達できな いという結論が得られた。

（2）目標位置の到達可能性：出発位置と目標位置をつなぐ 経路が存在する場合には，必ずそれを見い出せる.

これまでに上述の経路計画問題に対して Lumelsky の他に いくつかのアルゴリズムが提案されている，登尾らは作業環境 のトポロジーに基づき, 有限環境（Lumelsky のモデルでは作 業環境が無限）に関するいくつかのアルゴリズムを提案してい る[7]〜[9].これらのアルゴリズムはロボットのセンサとメ モりの種及の異なった要求に対応しており, ある種類の環境に 対しては良い経路が得られるものである.

上述のアルゴリズムはロボットを点としてモデル化するもの である，登尾ら[10]や楊ら [11]は実際のロボットの大きさを考 えて，ロボットを円とするモデルに基づくアルゴリズムを提案 している，また，文献[11]ではロボットが障害物を过回してい る時に障害物境界の接線の方向変化というトポロジー的性質に 基づき，一つの離脱点の評価基準が提案されている. しかし， このアルゴリズムは収束しない場合がある.

本論文では，文献[11]で提案された障害物境界の接線の方向 変化というトポロジー的性質に基づく一つのアルゴリズム（ロ ボットの大きさは考元られていない）を提案する，まず，問題 をモデル化してアルゴリズムを提案する，次に，アルゴリズム の収束性と目標位置の到達可能性を説明する。最後にグラフィ ックスシミュレーションによりアルゴリズムの有効性を確認す る.

提案するアルゴリズムは Bug 2 よりもっと積極的なアルゴ リズムであるといえる。ロボットの出発位置と目標位置が障害 物の “外”にある場合（3 章でこの場合を定義する)，このアル ゴリズムの経路の長さは多くの場合に Bug 2 や文献[ 8 ]のア ルゴリズムより短い。.また, 文献 $[7] や[9]$ に比べ, 環境のト ポロジー的性質の認識の計算が簡単で, 一般的に経路情報を記 憶するメモリが少ない利点がある。

\section{2. アルゴリズム}

\section{1 問題のモデル化}

実際の移動ロボットは多くの場合有限個の障害物を含む環境 で動く. 以下の仮定により問題をモデル化する.

（1）作業空間は有限個の任意の形状の障害物を含む二次元 の空間である，障害物の境界は簡単な閉鎖した交差しない曲線
であり，その周囲長は有限とする。 また，障害物同士は互いに 接触しないものとする，障害物がない空間は自由空間と呼ばれ る.

（2）移動ロボットは点で表現され（したがって，仮定(1) の作業空間は実際のロボットのコンフィギュレーション空間と みなしても良い), 自身の現在位置と目標位置を常に知ってい る、そして，作業環境における障害物の情報を予め持たない が, 内蔵された触覚センサにより現在障害物と接触しているか どうかを自ら判断できるものとする．また，センサ情報により 障害物の境界を辿ることができる.

（3）障害物の境界における鋭い点では，ロボットはセンサ 情報を修正し小さい円弧に沿って辿るとする。そうすると， 口 ボットが実際に辿った経路（以下に障害物の境界とみなす）で は接線の方向が連続的に変化する。

（4）移動ロボットは有限なメモりを持ち，通過した経路の 特徵を記憶できる.

ここで検討する問題は，出発位置と目標位置をつなぐ衝突回 避経路を計画するものである. トポロジーから見るとこの経路 は, 出発位置と目標位置をつなぐ自由空間における連続的な曲 線である.

\section{2 アルゴリズム}

ここで提案するアルゴリズムによる移動ロボットの経路は, いくつかの目標位置への直線経路と障害物の境界に沿う曲線経 路の系列から構成されるものである. 第 $i$ 番目の直線経路と障 害物の境界の交点は衝突点と呼ばれ， $H_{i}$ と書く。ここで直線 経路が終わり，曲線経路が始まる，第 $i$ 番目の曲線経路の終点 は離脱点と呼ばれ， $L_{i}$ と書く．ここで直線経路が始まる。口 ボットが障害物を辿る方向（以下に迂回方向と呼ぶ）は時計回 りと反時計回りの二つがあるので，予め一つの方向を決めてお く、ロボットは障害物を辿る時, 現在の迂回方向に応じる障害 物境界の接線単位ベクトル（センサ情報より計算できる） $\boldsymbol{r}_{t}$ と 現在位置から目標位置への単位ベクトル $r_{g}$ を計算する (Fig. 1 に時計回りの場合の $\boldsymbol{r}_{t}$ と $\boldsymbol{r}_{g}$ が示されている). $\boldsymbol{r}_{t}$ と $\boldsymbol{r}_{g}$ が成 す平面を $x-y$ 平面として三次元右手座標系を構成する. $(A)_{z}$

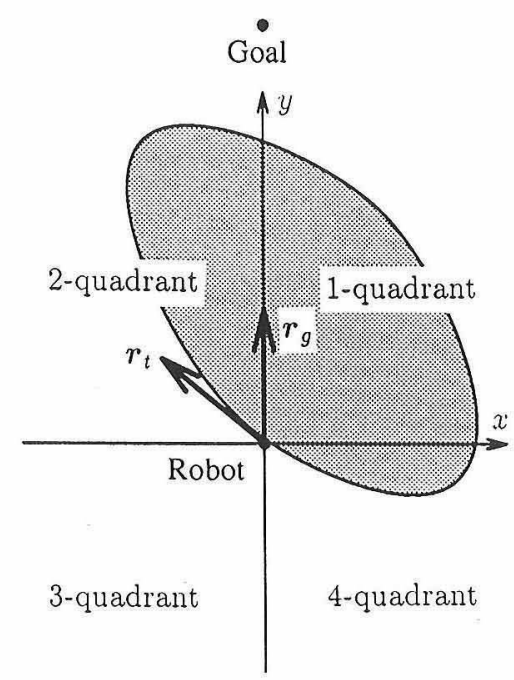

Fig. 1 Coordinate system 
Table $1 \quad\left(\boldsymbol{r}_{g} \times \boldsymbol{r}_{t}\right)_{z}$ and $\boldsymbol{r}_{g} \cdot \boldsymbol{r}_{t}$

\begin{tabular}{c|c|c|c|c}
\hline Quadrant & 1 & 2 & 3 & 4 \\
\hline$\left(\boldsymbol{r}_{g} \times \boldsymbol{r}_{t}\right)_{z}$ & - & + & + & - \\
\hline $\boldsymbol{r}_{g} \cdot \boldsymbol{r}_{t}$ & + & + & - & - \\
\hline
\end{tabular}

はベクトル $\boldsymbol{A}$ の $z$ 軸の成分を表す. Fig. 1のように $\boldsymbol{x}$ 軸と $\boldsymbol{y}$ 軸を設定すると， $x-y$ 平面の各象限に打けるべクトル $\boldsymbol{r}_{t}$ に対 して $\left(\boldsymbol{r}_{g} \times \boldsymbol{r}_{t}\right)_{z}$ と $\boldsymbol{r}_{g} \cdot \boldsymbol{r}_{t}$ の符号は Table 1 のように表される. Table 1 の二つのベクトル計算の符号により $\boldsymbol{r}_{t}$ と $\boldsymbol{r}_{g}$ の相対的 位置関係がわかる.

ロボットは次の五つのリストに，通過した衝突点と離脱点の 座標を記憶する。

（1）衝突点歴史リスト (時計回り)：時計回りの時に通過し た衝突点の座標を記憶する。

（2）衝突点歴史りスト (反時計回り)：反時計回りの時に通 過した衝突点の座標を記憶する。

（3）離脱点歴史リスト：通過した離脱点の座標を記憶す る.

（4）衝突点現在リスト：通過した衝突点の座標を記憶し， 辿る方向が変わる時にいままで記憶した情報を全部削除する.

（5）離脱点現在リスト：通過した離脱点の座標を記憶し， 辿る方向が変わる時にいままで記憶した情報を全部削除する.

以下に出発位置を $\mathrm{S}$, 目標位置を $\mathrm{G}$ とする．アルゴリズム は次のようになる。

始めに, $L_{0}=\mathrm{S}, j=1, N=0, M=0$ とする. 予め決められた 迂回方向（時計回り又は反時計回り）を記憶する（以下に記憶 した迂回方向を現在方向と呼ぶ）。ここで，N は経路のトポロ ジー的性質を記憶する変数であり， $M$ は目標位置が到達でき るかどうかを判断するための変数である.

（1）次の条件のうちのどちらかが満足されるまで，ロボッ 卜は離脱点 $L_{j-1}$ から目標位置への直線に沿って動く.

（a） G 点に到達したらアルゴリズムを終了させる，

（b）障害物に遭ったら，この点を衝突点 $H_{j}$ として現在方 向に関連する衝突点歴史リス卜と衝突点現在リス卜に座標を記 憶する.

それから，(2)へ。

（2）ロボットは $H_{j}$ から現在方向へ障害物を辿る. 動きな がら, $\left(\boldsymbol{r}_{g} \times \boldsymbol{r}_{t}\right)_{z}$ と $\boldsymbol{r}_{g} \cdot \boldsymbol{r}_{t}$ の符号の変化を監視する. 同時に次 の処理を行う.

（a） G 点に到達したらアルゴリズムを終了させる.

（b）目標位置が到達できるかどうかをチェックする. 現在 位置が衝突点現在リストに記憶した衝突点でありかつ離脱点現 在リストが空でない場合には， $M=1$ なら $M=0$ とする. 現在 位置が衝突点現在りストに記憶した衝突点でありかつ離脱点現 在リストが空である場合には， $M=0$ なら $M=1$ とし， $M=1$ なら目標位置は到達できないとして計算を終了する。このステ ップは ( 2)の (c) と同時に処理する.

(c) 現在位置が衝突点現在リストに記憶した衝突点であり かつ計算を終了しない場合には， $N=0, j=j+1$ とし，記憶し た現在方向を削除して反対方向を現在方向として記憶する。衝

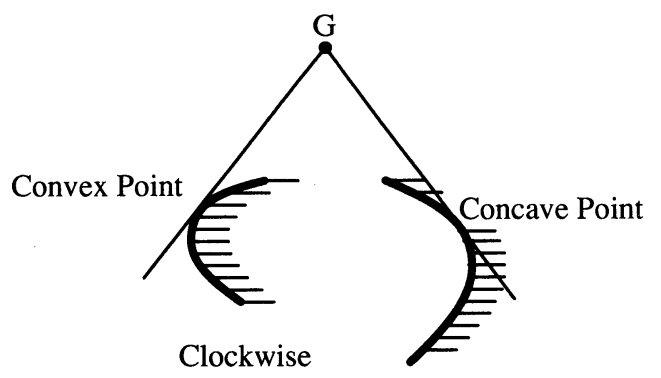

Fig. 2 Convex point and concave point

突点現在リストと離脱点現在リストに抢ける情報を全部削除 し，現在位置は衝突点 $H_{j}$ として現在方向に関連する衝突点歴 史リストと衝突点現在リストに座標を記憶する．現在方向へ障 害物を辿る。

（d）現在位置は現在方向に関連する衝突点歴史リストに記 憶したことがありかつ逆の方向に関連する衝突点歴史リストに 記憶していないなら， $N=0, j=j+1, M=0$ とし，記憶した現 在方向を削除して反対方向を現在方向として記憶する。衝突点 現在リストと離脱点現在リストに抢ける情報を全部削除し，現 在位置は衝突点 $H_{j}$ として現在方向に関連する衝突点歴史りス トと衝突点現在リストに座標を記憶する，現在方向へ障害物を 辿る。

（e ）障害物のトポロジーをチェックする，以下の結論は現 在方向が時計回りの場合であるが，反時計回りの場合には $\boldsymbol{r}_{t}$ の変化方向が反対となる． $\boldsymbol{r}_{t}$ が第 2 象限から第 1 象限 $(y$ 軸の 正部分を含む) に入る $\left(\left(\boldsymbol{r}_{g} \times \boldsymbol{r}_{t}\right)_{z}>0, \boldsymbol{r}_{g} \cdot \boldsymbol{r}_{t}>0\right.$ から $\left(\boldsymbol{r}_{g} \times \boldsymbol{r}_{t}\right)_{z} \leq$ $0, \boldsymbol{r}_{g} \cdot \boldsymbol{r}_{t}>0$ になる)と，N=N+1 とする． $N \neq 1$ なら，引続き 障害物を辿る． $N=1$ の場合には，この点が離脱点歴史リス卜 に記憶されていなければ，離脱点 $L_{j}$ とし離脱点現在リストと 離脱点歴史リストに座標を記憶して， $j=j+1, N=0$ として, （1）へ。この点が離脱点歴史リストに 1 回だけ記憶されていれ ば，記憶した現在方向を削除して反対方向を現在方向として記 憶する。衝突点現在リストと離脱点現在リストにおける情報を 全部削除し，現在位置は離脱点 $L_{j}$ として離脱点現在リストと 離脱点歴史リストに座標を記憶する. $N=0, j=j+1, M=0$ と し，（1）へ，この点が離脱点歴史リストに 2 回記憶されていれ ば，引続き障害物を辿る。

（f）障害物のトポロジーをチェックする．以下の結論は現 在方向が時計回りの場合であるが，反時計回りの場合には $\boldsymbol{r}_{t}$ の変化方向が反対となる. $\boldsymbol{r}_{t}$ が第 1 象限（ $y$ 軸の正部分を含 む) 加第 2 象限に入る $\left(\left(\boldsymbol{r}_{g} \times \boldsymbol{r}_{t}\right)_{z} \leq 0, \boldsymbol{r}_{g} \cdot \boldsymbol{r}_{t}>0\right.$ から $\left(\boldsymbol{r}_{g} \times \boldsymbol{r}_{t}\right)_{z}$ $>0, \boldsymbol{r}_{g} \cdot \boldsymbol{r}_{t}>0$ になる）と, $N=N-1$ とする.

以下では，上述のアルゴリズムで $N=N+1$ になる点（現在 方向が時計回りの場合には $\boldsymbol{r}_{t}$ が第 2 象限から第 1 象限 $(y$ 軸の 正部分を含む)に入る．現在方向が反時計回りの場合には $\boldsymbol{r}_{t}$ の 変化方向が反対である．アルゴリズムの $(2)$ の $(\mathrm{e})$ 参照)を凸 点と呼ぶ. $N=N-1$ になる点（現在方向が時計回りの場合に は $\boldsymbol{r}_{t}$ が第 1 象限 ( $y$ 軸の正部分を含む) から第 2 象限に入る. 現在方向が反時計回りの場合には $\boldsymbol{r}_{t}$ の変化方向が反対であ る.アルゴリズムの（2）の（f)参照）を凹点と呼ぶ．Fig. 2 に は現在方向が時計回りである時の凸点と凹点を示す. 
また，上述のアルゴリズムでは，ロボットが障害物を辿る時 に現在位置が次の二つの離脱条件のどちらかを満足すれば，離 脱点となって直線経路が始まる(アルゴリズムの (2)の（e ）．

\section{離脱点条件：}

（1）現在位置は凸点であり，N=1，かついままで離脱点歴 史りストに記憶されたことがない．

（2）現在位置は凸点であり，N=1，かついままで離脱点歷 史リストに 1 回だけ記憶されている.

ここで上述のアルゴリズムのステップ (1) の場合，この直線 がある障害物の一部分の境界に重なり合う時， ロボットはこの 障害物に遭わないとみなす。

\section{3. アルゴリズムの収束性と 目標位置の到達可能性}

本章では，まず自由空間を分類する，それからこの分類に基 づき，提案したアルゴリズムの収束性と目標位置の到達可能性 を証明する。

アルゴリズムによると，離脱点の必要条件は凸点である，口 ボットはこのような離脱点から目標位置への直線に沿って目標 位.置へ動ける。

\section{1 自由空間の分類}

定義 1 自由空間に属する点から出発する任意の半直線が少 なくとも一つの障害物と交差する時，この点はこれらの障害物 の内にあるという.

定義 2 自由空間に属する点加出発する半直線に全ての障 害物と交差しないかつ接しないものが存在する時，この点はこ れらの障害物の外にあるという。

\section{Fig. 3 参照.}

\section{2 目標位置も出発位置も障害物の外にある場合}

以下では，ロボットの目標位置も出発位置も障害物の外にあ る場合を考える。まず，作業空間に障害物が一つしかない場合 を考える，以下の証明では一般性を失うことなく初めの迂回方 向を時計回りとする，反時計回りの場合も同様に証明できる.

ロボットの目標位置と出発位置をつなぐ直線 SGがこの障害 物と交差しなければ，アルゴリズムによりロボットは S 点か

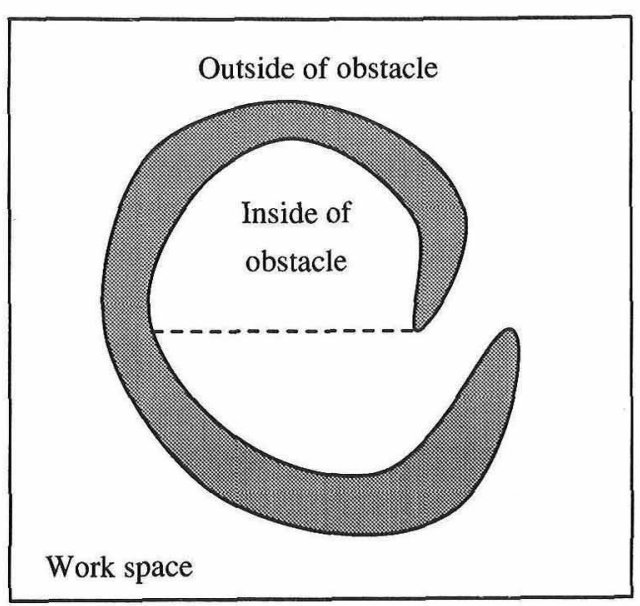

Fig. 3 Classification of free space
ら直線 SG に沿って目標位置に到達できる，以下に直線 SG が この障害物と交差する場合を考光る，G点が障害物の外にある ので, $\mathrm{G}$ 点から出発する半直線には，障害物に接しかつ接点の 他には障害物の境界と交差しないものが 2 本存在する。このよ うな二つの接点のうち必ず一つは時計回りの時の凸点である. 以下ではこの接点を $\mathrm{A}$ 点と呼び，もう一つの接点を $\mathrm{B}$ 点と呼 ぶ (Fig. 4 参照).

$\mathrm{S}$ 点が障害物の外にあるので, 同様に $\mathrm{S}$ 点に対してこのよう な 2 本の接線が存在する。: 二つの接点はそれぞれ $\mathrm{C}$ 点， D 点 と呼ばれる。したがって，障害物は Fig. 4 の斜線領域にしか 存在しない. そして，アルゴリズムによる経路も Fig. 4 の斜 線領域にしか存在しない.

定理 1 作業環境に一つの障害物しかなくかつロボットの出 発位置も目標位置もこの障害物の外にある場合，直線 SG がこ の障害物と交差すれば，アルゴリズムにより目標位置に到達で きる経路は必ず A 点に到達する。

証明：ロボットは S 点から直線 SG に沿って目標位置へ動 き，障害物に遭うと衝突点 $H_{1}$ 汃ら時計回り方向へ障害物を辿 る。もし目標位置に到達できる経路が A 点を通過しないな

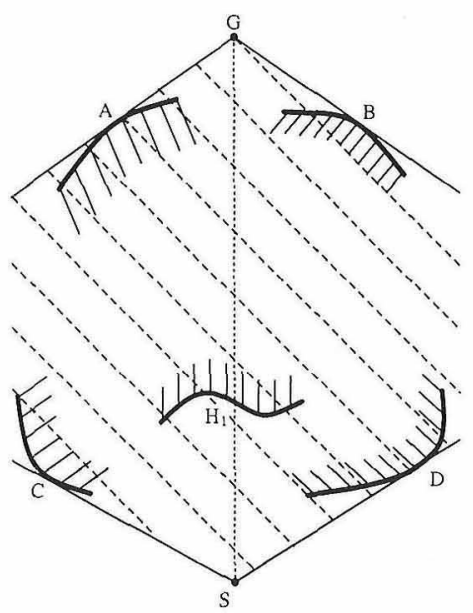

Fig. 4 Region of path

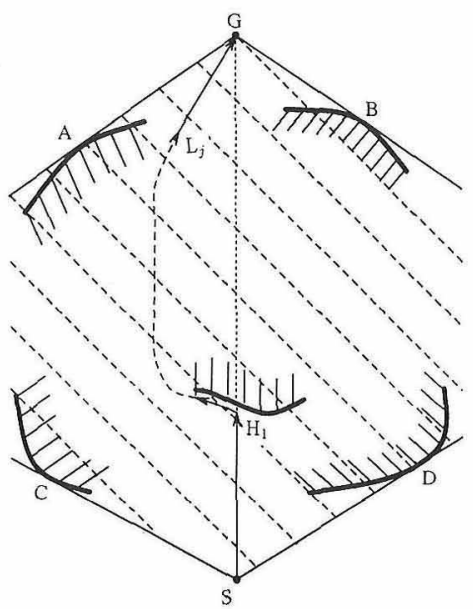

Fig. 5 Proof of theorem 1 

する．よって，定理 1 が証明された。 た点はない。 二つの命題を証明する。 生じた衝突点には到達できない.

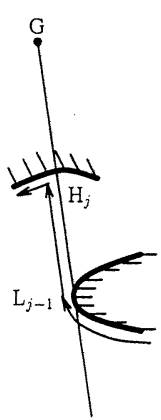

(a)
ら，必ず Fig. 4 の斜線領域に離脱点 $L_{j}$ が存在し， $L_{j}$ から直 線に沿って目標位置に到達できる。したがって，斜線領域には Fig. 5 のようにA 点を通過しない経路が存在する．そうする と, この経路は斜線領域を二つの部分に分け, A 点の近傍の 障害物の境界と $H_{1}$ 点の近傍の障害物の境界がこの経路の両側 にあることになる，つまり，障害物は自由空間により二つの部 分に分けられることになる。これは一つの障害物の仮定に矛盾

定理 2 作業環境に一つの障害物しかなくかつロボットの出 発位置も目標位置もこの障害物の外にある場合, 直線 SG がこ の障害物と交差すれば，A 点に着く前の経路には 2 回通過し

証明：ロボットは S 点から直線 SG に沿って目標位置へ動 き，障害物に遭うと衝突点 $H_{1}$ から時計回り方向へ障害物を辿 る．障害物の境界が閉鎖した交差しない曲線なので，ロボット は A 点に着く前に他の離脱点を通過しなければ，必ず $\mathrm{A}$ 点に 着く，そして，このような経路には 2 回通過した点がない.

$\mathrm{A}$ 点に着く前にロボットの経路が離脱点に着くと, 定理 1 により新しい衝突点を生じる. $\mathrm{S}$ 点から $H_{1}$ 点までの直線経路 は自身交差しない，障害物の境界が交差しない曲線であるか ら， $H_{1}$ から $L_{1}$ までの曲線経路は自身交差しない。，そして, アルゴリズムの $(1)$ により，この曲線経路は $\mathrm{S}$ 点から $H_{1}$ 点ま での直線経路と交差しない．したがって，離脱点 $L_{1}$ までの経 路には 2 回通過した点はない。一般性を失うことなく, A 点 以外の離脱点 $L_{j-1}(j \geq 2)$ までの経路には 2 回通過した点がな いと仮定する，離脱点 $L_{j-1}$ からの経路を考える．まず，次の

（1）新しい衝突点 $H_{j}$ は通過したことがない点である.

(2) 衝突点 $H_{j}$ から次の離脱点 $L_{j}$ までの経路はいままで

（1）Fig. 6 の（a）に示すように衝突点 $H_{j}$ の後の隣接の経 路と離脱点 $L_{j-1}$ に着く前の隣接の経路は直線 $L_{j-1} \mathrm{G}$ の両側に ある．衝突点 $H_{j}$ は通過したことがあると仮定すると，上述の 二つの部分の経路は必ずつながっている．したがって，その経 路は直線 $L_{j-1} \mathrm{G}$ と交差しなければならない，離脱点 $L_{j-1}$ まで の経路には 2 回通過した点がないことにより, 交点 $\mathrm{E}$ は Fig. 6 の ( b ) と (c )の二つの場合だけである.（b ) の場合は図に示す ような閉鎖した経路が存在し，障害物はこの経路により二つの

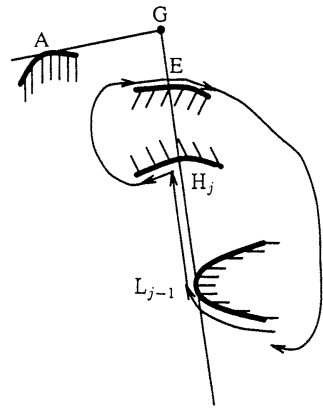

(b)

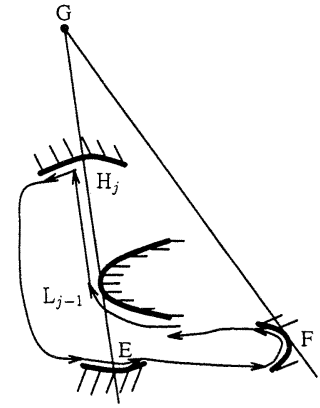

(c)
部分に分けられる。これは一つの障害物の仮定に矛盾する. (c)の場合は図に示すような閉鎖した経路が存在する。そし て， $\mathrm{E}$ 点と離脱点 $L_{j-1}$ の間には必ず $\mathrm{F}$ 点のような凹点が存在 する. 離脱点 $L_{j-1}$ までの経路には 2 回通過した点がないの で，アルゴリズムの $(2)$ の $(\mathrm{e})(\mathrm{f})$ により， $\mathrm{F}$ 点後の経路では $N<0$ となり， $L_{j-1}$ 点は離脱点条件を満足しない（E 点と離脱 点 $L_{j-1}$ の間に一つ以上の凹点と凸点が存在する場合には，定 理 3 の証明と同様に，やはり $L_{j-1}$ 点が離脱点条件を満足しな いことが証明できる)。これは仮定に矛盾する，以上により， 衝突点 $H_{j}$ はロボットがいままで通過したことがない点であ る.

（2）ロボットの出発位置は障害物の外にあるので，衝突点 $H_{1}$ からの経路はもう 1 回衝突点 $H_{1}$ に着くことはできない.

衝突点 $H_{j}$ から次の離脱点 $L_{j}$ までの経路を考元る。この部 分の経路が衝突点 $H_{j}(i \leq j$ and $i \neq 1)$ に着くと仮定する. Fig. 7 の (a) に示すように衝突点 $H_{j}$ の後の隣接の経路と離脱点 $L_{j-1}$ に着く前の隣接の経路は直線 $L_{j-1} \mathrm{G}$ の両側にある. した がって, $H_{j}$ 点から $H_{i}$ 点までの経路と $H_{i}$ 点と $L_{j-1}$ までの経 路のどちらかが必ず直線 $L_{j-1} \mathrm{G}$ と交差する，ロボットの経路 は自身交差しないので，離脱点 $L_{j-1}$ に着く前の経路には 2 回 通過した点がないことにより, 交点 E は Fig. 7 の (b) と (c) の二つの場合だけである．罒に示すように，二つの場合はどち らの場合もロボットの経路が障害物を二つの部分に分ける。こ れは一つの障害物という仮定に矛盾する.したがって，命題 ( 2 ) が証明された.

以上二つの命題により, $\mathrm{A}$ 点以外の離脱点 $L_{j-1}$ までの経路 に 2 回通過した点がなければ，離脱点 $L_{j-1}$ から次の離脱点 $L_{j}$ までの経路には 2 回通過した点がない. 離脱点 $L_{1}$ までの経路 には 2 回通過した点がないので, 定理 2 は証明された。

定理 1 と定理 2 により，上述の場合には A 点までのロボッ トの経路では, 衝突点歴史リストと離脱点歴史リストに記憶し た点にもう一度到着することがないので，迂回方向は変わらな い(アルゴリズムの $(2) の(\mathrm{c})(\mathrm{d})(\mathrm{e}))$ 。そして，アルゴリズ 厶の (2)の (b) (c)（d）の操作は行っていず，ロボットは必ず A 点洋着く.

定理 3 作業環境に一つの障害物しかなくかつロボットの出

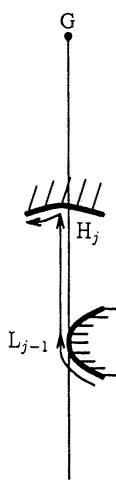

(a)

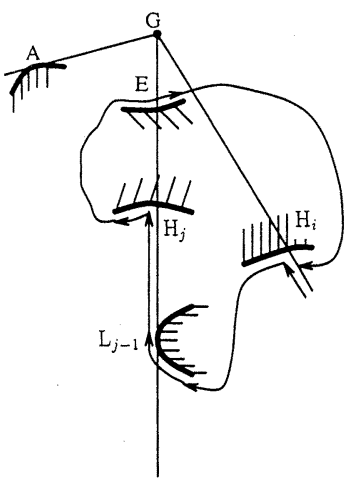

(b)

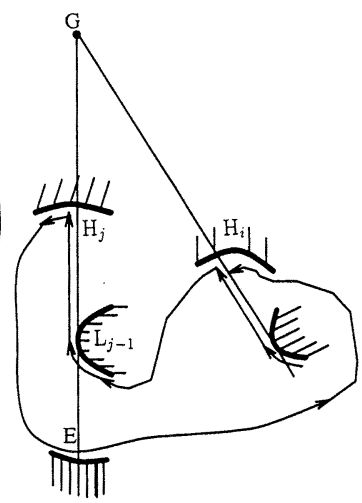

(c)
Fig. 6 Proof of proposition (1) of theorem 2

Fig. 7 Proof of proposition (2) of theorem 2 


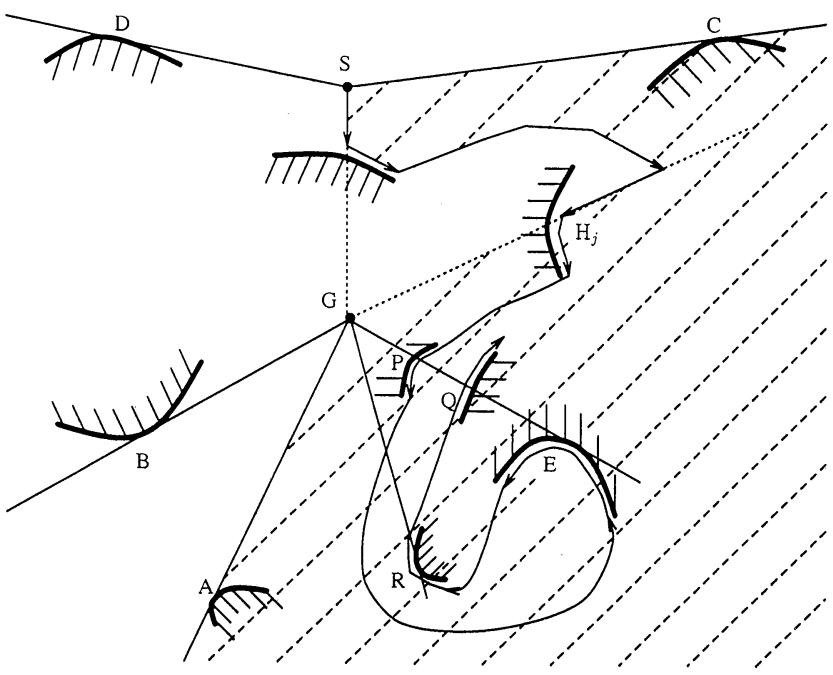

Fig. 8 Proof of theorem 3(1)

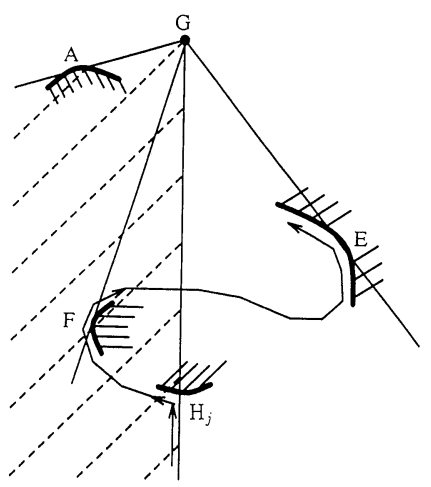

Fig. 9 Proof of theorem 3 (2)

発位置も目標位置もこの障害物の外にある場合, 直線 SGがこ の障害物と交差すれば，A 点は離脱点である.

証明：ロボットは S 点から直線 SGに沿って目標位置へ動 き，障害物に遭うと衝突点 $H_{1}$ から時計回り方向へ障害物を辿 る.もしロボットが A 点に着く前に凹点を通過しなければ, $\mathrm{A}$ 点に着く直前では $N=0$, したがって $\mathrm{A}$ 点は離脱点条件を満 足して離脱点となる.

以下では，ロボットが $\mathrm{A}$ 点に着く前に凹点を通過する場合 を考える。

一般性を失うことなく, $\mathrm{A}$ 点に着く直前の衝突点 $H_{j}$ からの 経路を考える. $H_{j}$ 点では $N=0$ である. $H_{j}$ 点から $\mathrm{A}$ 点まで の経路には離脱点と $H_{j}$ 点以外の衝突点はない.つまり，この 部分の経路は障害物の境界に沿う経路である.

衝突点 $H_{j}$ 点からの経路の始めの凹点は $\mathrm{E}$ 点と呼ばれ，必ず Fig. 8 に示すような斜線部分 (半直線 $\mathrm{SC}, \mathrm{S}$ 点から $H_{j}$ 点まで の経路，線分 $\mathrm{G} H_{j}$ と半直線 $\mathrm{GA}$ が囲む領域）にある。なぜな ら，Fig.9のようにE点が斜線部分になければ，ロボットの 経路は自身交差しないので， $H_{j}$ 点と $\mathrm{E}$ 点の間の経路が必ず線 分 $\mathrm{GH}_{j}$ と交差する. したがって図のように, $H_{j}$ と $\mathrm{E}$ 点の間 には離脱点条件を満足する凸点 $\mathrm{F}$ 点が必ず存在し $\left(H_{j}\right.$ 点と $\mathrm{E}$

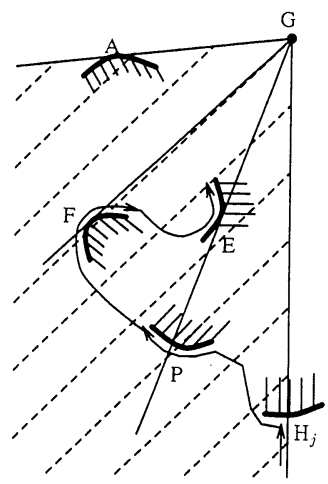

Fig. 10 Proof of theorem 3 (3)

点の間の経路には凹点がない)，仮定と矛盾する.

半直線 $\mathrm{GH}_{j}$ は上述の斜線部分を二つの部分に分ける. $\mathrm{E}$ 点 が半直線 $\mathrm{SC}, \mathrm{S}$ 点から $H_{j}$ 点までの経路と半直線 $\mathrm{G} H_{j}$ が囲む 領域にあると，必ず線分 $\mathrm{GE}$ が $H_{j}$ 点に着く前の経路あるいは 半直線 $\mathrm{GC}$ と交差する。 $\mathrm{E}$ 点が半直線 $\mathrm{G} H_{j}$ と半直線 $\mathrm{GA}$ が囲 む領域にあると，必ず線分 $\mathrm{GE}$ が $H_{j}$ 点から $\mathrm{E}$ 点までの経路と 交差する。なぜなら， $\mathrm{E}$ 点が半直線 $\mathrm{G} H_{j}$ と半直線 $\mathrm{GA}$ が囲む 領域にあると, $\mathrm{E}$ 点の近傍の経路と $H_{j}$ 点の近傍の経路は半直 線 GE の両側にあるからである (Fig. 8 参照). E 点に着く前の 経路が半直線 $\mathrm{GE}$ と交差する点を $\mathrm{P}$ 点と呼ぶ. $\mathrm{P}$ 点が線分 $\mathrm{GE}$ 上にないとすると，Fig. 10 に示すように，E点に着く前に離 脱点条件を満足する凸点 $\mathrm{F}$ 点に到達し，仮定と矛盾する。だ から，P点は必ず線分 $\mathrm{GE}$ 上にある。したがって，線分 $\mathrm{GE}$ は $\mathrm{E}$ 点に着く前の経路あるいは半直線 $\mathrm{SC}$ と交差する.

そうすると, Fig. 8 に示すように $\mathrm{E}$ 点後の経路は， E 点に着 く前の経路 (半直線 SC を含む) と線分 PE が作る閉じた領域に ある. その後の経路はこの領域から出るために線分 PE と交差 しなければならない。この交点 $(\mathrm{Q}$ 点)と $\mathrm{E}$ 点の間には必ず凸 点 $(\mathrm{R}$ 点) がある。したがって，凹点 $\mathrm{E}$ 点後の経路には必ず凸 点 ( $\mathrm{R}$ 点)がある.

$\mathrm{Q}$ 点後の経路に凹点があれば，同様に閉じた領域が存在し， 閉じた領域から出るためには必ず R 点以外の凸点が存在す る.そうすると， $H_{j}$ 点から A 点までの経路には山点と凸点が 対になって生じ, A 点に着く直前には $N=0$ となる（アルゴリ ズムの(2)の(e)(f))。したがって，A点に着くと $N=1$ と なり $\mathrm{A}$ 点は離脱点である。よって定理 3 は証明された。

ロボットは $\mathrm{A}$ 点に到着後は，直線 $\mathrm{AG}$ に沿って目標位置 $\mathrm{G}$ 点に到達できる。したがって，作業環境に一つの障害物しかな くかつロボットの出発位置も目標位置もこの障害物の外にある 場合に対して，アルゴリズムの収束性と目標位置の到達可能性 が証明された。

複数の障害物の場合には障害物の数が有限であるので，同様 にアルゴリズムの収束性と目標位置の到達可能性が証明でき る.

\section{3 他の場合}

次に，目標位置と出発位置どちらか又は両方とも障害物の内 にある場合を考える。この場合にはロボットが障害物を辿る時 に通過した経路をもう一度通過する場合があり，経路に閉鎖し 
元 司毛利彰

たループが存在する.

ロボットの経路では各衝突点での動き方が二つ（時計回りと 反時計回り）しかなく，各離脱点での動き方が三つ（現在方向 を記憶して離脱，現在方向の逆方向を記憶して離脱および離脱 しない）しかない。この場合のアルゴリズムは，衝突点歴史リ ストと離脱点歴史リストに記憶した情報に基づき，Fig. 11 に 示すように縦型探索法により各衝突点と離脱点の動き方を一つ ずつ探索し(アルゴリズムの ( 2 )の ( c ) (d) ( e ))，ある離脱点 から直線に沿って目標位置に到達できれば，経路が見つかった として計算を終了する。このような離脱点がなければ，有限回 の繰り返しの後ですべての離脱点を 2 回通過し（離脱点歴史り ストに 2 回記憶)，障害物を辿る時に離脱点がなくなり(アルゴ リズムの（2）の(e ))，したがってロボットは離脱せず衝突点 に戻るようになる，この時には可能経路がないとして計算を終 了する(アルゴリズムのステップ（2)の（b)). したがって，ア ルゴリズムの収束性が保証された。

以下にアルゴリズムの目標位置の到達可能性を説明する。目

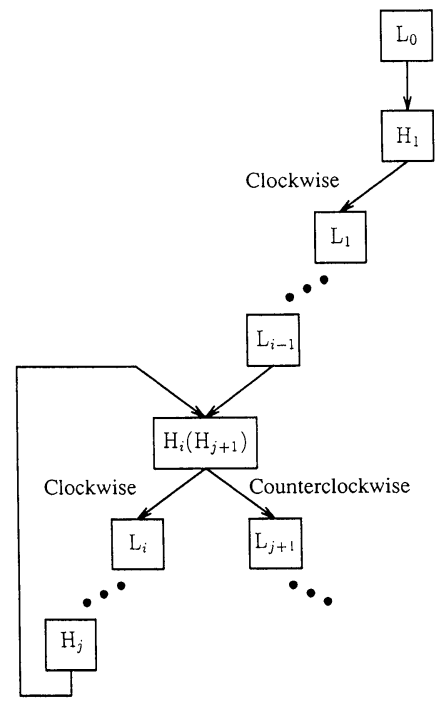

Fig. 11 Depth-first search

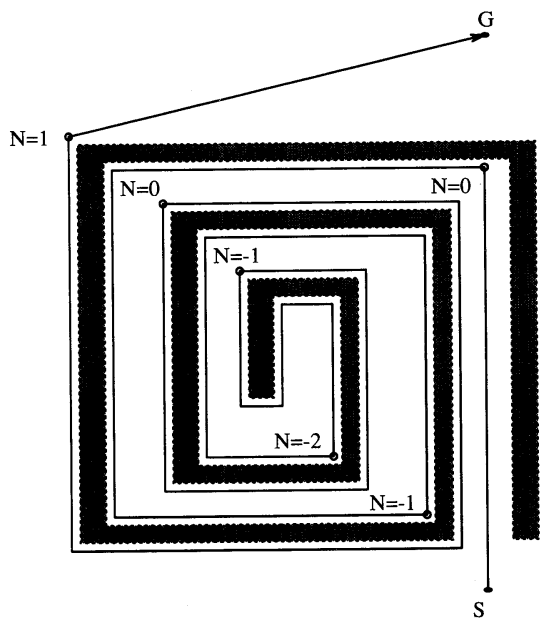

Fig. 12 Simulation (1)
標位置と出発位置どちらか又は両方とも障害物の内にあり，そ して実行可能経路が存在する場合を考える．アルゴリズムを適 用する際にその境界上の点が衝突点となる障害物には, 目標位 置までの直線がその障害物自身と交わらないような凸点が必ず 存在する。ロボットがこの障害物を辿って可能経路がないとい う結果を得る前に，この凸点に少なくとも 1 回は到着する。し かし，その時にこの凸点が離脱点条件を満足するかどうかはま だ厳密には証明されていない. したがって，この場合には提案 したアルゴリズムはヒューリスティックなものである。しか し，アルゴリズムによりいままで行った様々なシミュレーショ ン例では目標位置の到達可能性が保証されている.

上述の説明により，出発位置と目標位置が障害物の外にある 場合，離脱点が $\mathrm{A}$ 点のような接点であることから，このアル ゴリズムの経路の長さは多くの場合 Bug 2 や文献 $[8]$ のアル ゴリズムより短い.したがって，このアルゴリズムはより積極 的なアルゴリズムであるといえる。そして文献 $[7] や[9] と$ 比 ベ，環境のトポロジー的性質の認識の計算が簡単で，一般的に 経路情報を記憶するメモリが少ない利点がある.

\section{4. シミュレーション例}

提案したアルゴリズムにより，様々なグラフィックスシミュ レーションを行った．以下に四つの例を示す．Fig. 12 と Fig. 13 はロボットの出発位置と目標位置が障害物の外にある場合

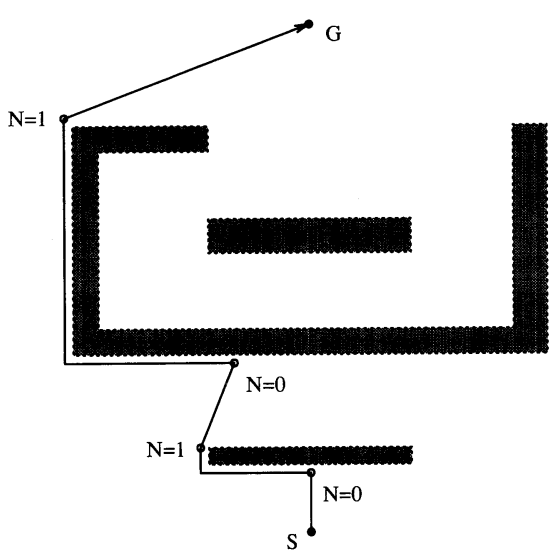

Fig.13 Simulation（2)

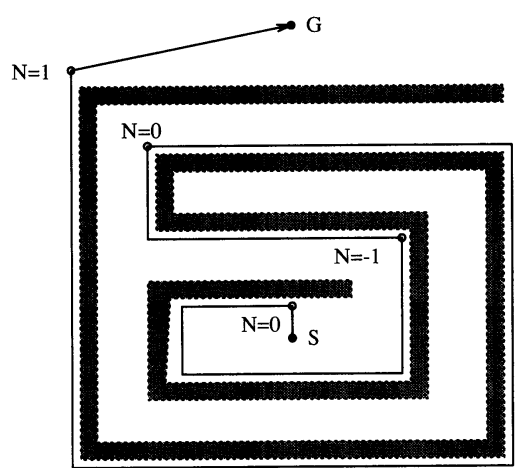

Fig. 14 Simulation ( 3 ) 


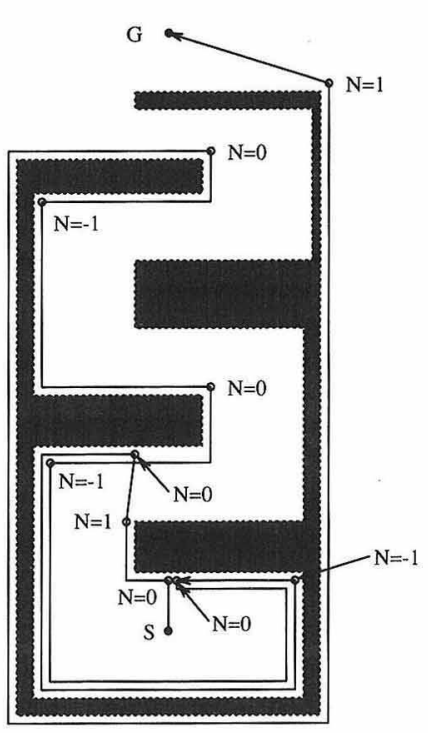

Fig. 15 Simulation (4)

を示す。この二つの例では提案したアルゴリズムの経路は Bug 2 や文献 $[8]$ の経路より短い. Fig. 14 と Fig. 15 はロボッ トの出発位置が障害物に囲まれた領域にある例 (Fig. 15 は文献 [6]の一つの問題に対する経路) である.

\section{5.あと がき}

本論文では，二次元未知環境における移動ロボットの衝突回 避経路計画問題について，環境のトポロジー的性質に基づいた 一つの積極的なアルゴリズムを提案した。 そして，シミュレー ション例により提案したアルゴリズムの有効性を検証した。

一方，アルゴリズムの目標位置の到達可能性はまだ厳密には 証明されていない.今後の課題としては,

（1）アルゴリズムの目標位置の到達可能性を証明する.
（2）実行可能経路が存在するにもかかわらず目標位置に到 達できない例を見い出し，アルゴリズムを改善する. などが挙げられる。

\section{参 考 文 献}

[1] J. T. Schwartz and M. Sharir: "On the piano movers' problem: I. The case of a two-dimensional rigid polygonal body moving amidst polygonal barriers," Comm. Pure Applied Math., vol. 36, pp. 345-398, 1983.

[2] V. Lumelsky and K. Sun: "A unified methodology for motion planning with uncertainty for 2D and 3D two-link robot arm manipulators," Int. J. Robotics Res., vol. 9, no. 5, pp. 89-104, 1990.

[ 3 ] V. Lumelsky and A. Stepanov: "Dynamic path planning for a mobile automaton with limited information on the environment," IEEE Tran. Automa. control, vol. AC-31, no. 11, pp. 1058-1063, 1986 .

[4] V. Lumelsky and A. Stepanov: "Path planning strategies for a point mobile automaton moving amidst unknown obstacles of arbitrary shape," Algorithmica, vol. 2, pp. 403-430, 1987.

[5] V. Lumelsky and T. Skewis: "Incorporating range sensing in the robot navigation function," IEEE Tran. Syst. Man Cybern., vol. 20, no. 5, pp. 1058-1069, 1990.

[6] V. Lumelsky: "A comparative syudy on the path length performance of maze-searching and robot motion planning algorithms," IEEE Tran. Roboti. Automa., vol. 7, no. 1, pp. 57-66, 1991.

[7] 吉岡, 登尾：“作業空間のトポロジーとパスプランニングアルゴリズ ムのデッドロック生起との関係についで,第 10 回日本ロボット学会 学術講演会予稿集, pp. 781-784, 1992.

[ 8 ] 服部, 登尾: “空間形状に応じて距離関数を動的に変化させるセンサ ベーストパスプランニングアルゴリズム”, 第 11 回日本ロボット学会 学術講演会予稿集, pp. 1063-1066, 1993.

[ 9 ] 吉岡, 登尾：“連続/再帰記憶によるセンサベーストパスプランニン グ”, 第 11 回日本ロボット学会学術講演会予稿集, pp. 1067-1070, 1993.

[10] 登尾, 橋目：“可能領域を持つ移動ロボットの未知空間における実際 的なパスプランニングアルゴリズム”，日本ロボット学会誌，vol. 10, no. 3, pp. 378-384, 1992.

[11］楊, 山本, 毛利：“ポテンシャル関数を用いる複雑な環境における移動 ロボットの衝突回避経路計画”, 日本機械学会九州支部第 47 期総会講 演会講演論文集, pp. 277-280, 1994.

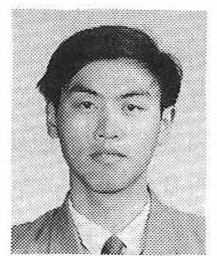

楊 向東 (Xiang Dong Yang)

1966 年 5 月 17 日生. 1989 年, 中国清華大学精密 計器系卒業. 1992 年から 1994 年まで, 九州大学 工学部知能機械工学科留学. 1994 年中国清華大学 精密計器系博士課程卒業. 現在清華大学教官. 口 ボットモーションプランニングの研究に従事.

（日本ロボット学会正会員）

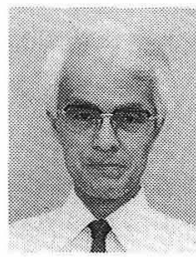

\section{毛利 彰 (Akira Mohri)}

1941 年 6 月 23 日生. 1969 年九州大学大学院工学 研究科博士課程単位取得退学(生産機械工学専 攻). 同年九州大学工学部講師. 助教授を経て, 82 年同教授, 現在に至る。ロボット工学, 制御工学 の研究に従事. 日本機械学会, 計測自動制御学会 などの会員. （日本ロボット学会正会員）

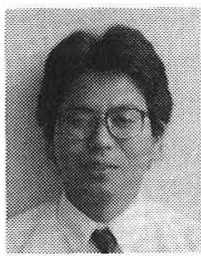

山本元司 (Motoji Yamamoto)

1962 年 7 月 10 日生. 1990 年九州大学大学院工学 研究科博士後期課程修了 (生産機械工学専攻). 同 年九州大学工学部講師. 92 年同助教授, 現在に至 る. ロボット工学の研究に従事. 日本機械学会, 計測自動制御学会などの会員.

（日本ロボット学会正会員） 